陈学鹏 封崇崇

泰安岳首筑路机械有限公司

DOI:10.32629/ems.v2i2.696

[摘 要] 机械工程具有着动态性,是推动机械行业获得健康发展的关键性因素。机械具有自动化、智能化等特征,机 械工程促使机械动态特征得以充分发挥。而机械设计则是机械工程的基础,高质量的机械设计赋予了机械工程与机 械设计源源不断地发展动力。本文就此分析了机械设计在机械设计与制造中的重要性。以期给相关工作者带来一定 借鉴意义与参考价值。

[关键词] 机械设计;机械制造;作用

快速发展的信息技术, 为各行各业的持续性发展提 供了先进的技术支持。同时, 随着人们物质生活水平的不 断提升, 人们对产品质量也提出了更高的要求。作为产品 生产单位, 只有不断更新与优化生产标准, 方可以生产出 满足市场需要的高质量产品。作为机械制造行业, 通过重 新审视机械设计与机械制造二者间的关系, 制定出富有 针对性与科学合理性的生产策略。

的基础上, 选择合理的填土材料, 在材料的选择上, 一定 要以现场的土体结构为参考依据。如果土质较干的话, 要选择与土质水含量相对应的填充材料, 控制土质含水 量在合理范围; 如果土质含水量较低的话, 会造成土体 结构不稳定的现象, 填土材料在送检达标后才能使用。 科学地选择填土材料, 保证基础设施建设的顺利开展, 为 整个工程的安全性奠定基础与保障。

\section{3 严格控制基础土方的施工流程}

在基础土方的施工活动中, 要充分的发挥出管理与 监管的作用。在土方的挖掘活动中, 要将多余的土方送 至较远处。因为, 在挖掘土方的过程中, 地基四周的土质 较为松软, 在多余土方的压力下, 可能会造成坞塌现象, 而一旦出现坍塌现象时, 会极大程度的影响整体的施工 效率与质量。此外, 在基础土方的挖掘活动中, 通常有时 间的限制, 管理人员与技术人员要通力合作, 保证土方挖 掘工作的正常开展。

\section{4 健全施工制度}

在房屋建设施工活动中, 健全的施工规范制度能弥 补施工缺陷, 保证施工活动的顺利开展。然而, 现阶段, 我 国依然缺少一个健全的房屋建设施工制度, 无形中给施 工活动埋下了安全隐患。因此, 有关部门要加强对房屋 建设施工制度的建设工作。此外, 在施工场地的选择方 面, 也要引起充分的重视, 加强对施工现场土质构造的考 察工作, 同时, 结合本地的气候变化情况, 为顺利施工奠

\section{1 机械设计和机械制造发展现状}

从生产管理来看,发达国家在机械制造管理工作中, 给予了计算机技术与机械制造模式或者管理体制建设 足够的重视。相较于发达国家, 我国较大比例的机械制造 企业受到资金实力等方面的影响, 在实际的管理工作中 仍采用着较为传统的管理方法, 这在很大程度上影响到 机械制造效率,并制约了制造企业的持续性发展。

定坚实的基础与保障。在施工方案的选择方面, 设计人 员要反复论证方案的合理性、安全性, 以及可行性[4]。

\section{5 结束语}

综上所述,在房屋建设基础土方的施工活动中,土方 施工质量与整体建筑质量之间成正比关系。随着城市化 进程的不断加速, 房屋建设基础土方工程的发展也迈人 了快车道, 始终在困难中前行, 在前行中开创进取。在市 场经济背景下,建筑行业之间的竞争不断向白热化演变, 基础土方施工作为重要的施工环节, 一定要引起建筑企 业的重视,提高基础土方施工技术的应用,不仅提高了房 屋建筑的整体质量,还能提高企业的市场竞争力。

\section{[参考文献]}

[1]吉雷三.基坑围护和土方开挖技术在房屋建筑施 工中的应用[J].经济技术协作信息,2018(15):83+83.

[2]谭艳平. 房屋建筑混凝土和土方施工技术要点分 析[J].低碳世界,2019,9(6):145+146.

[3]刘李永, 许子俊.道桥工程中土石方开挖回填施 工技术的运用[J].智能城市,2019,5(7): $105+106$.

[4]黄小军. 基坑围护和土方开挖技术在房屋建筑施 工中的应用[J].建材与装饰,2018,(36):22 + 23 .

\section{作者简介}

姓名: 徐福龙; 性别: 男; 民族: 汉; 籍贯: 山东; 身份 证号:371321199007025838 
其次,机械设计。计算机技术是机械设计工作顺利进行的 技术支持, 同时, 也是设计规则与设计数据得到快速处理 的关键性技术。然而,我国在计算机辅助设计领域的专业 性人才较少, 此现状直接影响到机械设计质量与设计效 率。

再次,自动化设备。经过长时间的发展,机械制造技 术逐步呈现出信息化、现代化与智能化。这也使得机械 制造企业面临了较大的生存压力。只有不断提升自身的 生产能力,方可以更好的提升市场竞争力。

最后, 制造工艺。西方发达国家在机械制造过程中, 有效融合了微细加工、精细加工、电磁加工、高精密加 工、复合加工等多种技术。我国机械制造行业在生产过 程中恰恰缺乏对这些先进技术的有效应用, 进而影响到 整个行业的健康发展。

\section{2 机械设计阶段划分}

以下内容从计划阶段、方案设计阶段、技术设计阶 段三个方面对机械设计工作进行了相应分析。

首先, 计划阶段。在开始设计前, 设计人员需要全面收集 了解与机械设计相关的材料。通过分析发现机械设计过 程中面临的优势与劣势, 提前制定出各项防控措施, 有效 规避到设计过程中的问题, 使得最后设计出的方案满足 现实生产需要。

其次,方案设计阶段。方案设计过程中,设计人员需 要结合设计原则、设计理论等来有效调节设计期望与客 观条件、设计结果三者间的关系,提升设计方案的科学合 理性。在图纸绘制过程中, 设计人员需要结合现实需要选 择科学合理的绘制手段。图纸绘制完成后, 要将图纸交由 专业人员审查, 审查通过后方可以进行后续施工操作。

再次,技术设计。此阶段结合总装配草图与部件装配 草图对产品进行科学合理设计。在设计过程中, 设计人员 需要全面融合审查意见与建议, 并以此提升技术设计水 平与质量。在后续的机械制造生产过程中, 设计人员需要 结合现实需要不断更新与优化设计方案, 以此保证技术 设计达到最优状态。随着生产规模的扩大, 在生产过程中 会出现大批量生产现象, 为了提升生产质量, 技术设计人 员需要给予模具设计工作足够的重视。

\section{3 机械设计未来发展趋势}

随着科学技术的快速发展, 各行各业均面临了前所
文章类型: 论文 | 刊号( ISSN ):2705-0637(P)/2705-0645(O)

未有的挑战。对于机械设计与机械制造而言,也需要顺应 时代发展趋势, 不断更新与优化设计理念与制造技术。以 下内容分析了机械设计未来的发展趋势。

\section{1 向虚拟化方向发展}

将虚拟化技术应用于机械制造产品加工、生产工艺 等各个方面, 不仅可以降低企业生产成本, 也可以更新与 优化生产周期。此外, 将计算机仿真模拟软件应用于机械 设计中, 大力提升了机械产品设计与制造工艺的稳定性, 保证了生产周期的平稳性, 并将生产过程中的错误概率 降到最低,提升了机械设计与制造质量与效率。

\section{2 自动化水平逐步提升}

随着科学技术的快速发展, 机械制造自动化水平逐 步提升,有效整合了集成系统技术、单一技术与柔性技术 等多种技术类型。这不仅为机械制造企业营造了良好的 发展空间,也为机械制造自动化发展奠定了坚实基础。

\section{3 绿色化程度逐步提升}

随着技术水平的不断提升, 机械制造生产逐步加大了绿 色设计理念应用力度, 并将材料、设备、工艺、管理等融合 为一体, 为机械制造绿色生产提供了良好的条件。另外, 绿色化程度的提升, 也降低了机械制造过程中对周围环 境的负面影响。在全面提升能源与原材料利用率的基础 之上,为机械制造获得持续性发展。

\section{4 结束语}

机械设计科学合理性直接关系到机械制造质量与 机械制造效率, 也关系到机械工程能否获得持续性发展。 在科学技术快速发展的大环境下, 本文从机械设计与机 械制造发展现状、机械设计阶段划分与机械设计未来发 展趋势三个方面分析了机械设计在机械制造中的重要 性。希望可以给相关工作者带来借鉴与参考, 并促进机械 制造行业获得持续性、快速、健康发展。

[参考文献]

[1]董大伟.机械设计与机械制造的技术分析 [J].工 业技术,2018(39):176.

[2]杨杞. 机械设计与机械制造的技术分析[J]. 黑龙 江科技信息,2016(22):59.

[3]谭国辉.浅谈新背景下机械设计与制造中的绿色 设计法[J]. 房地产导刊,2014(4):128. 